\title{
Poklicno izobraževanje v kognitivni ali informacijski družbi
}

$V$ zadnjih treh letih, torej po tem, ko je bila sprejeta nova šolska zakonodaja, so slovenski dnevniki pretežno pisali o šolskih novostih v osnouni šoli ali kvečjemu še na prehodu s srednje šole na univerzo, torej $v$ zvezi z maturo. Po takšnem pisanju bi labko sklepali, da je oko javnosti in tudi stroke obrnjeno predvsem k obveznemu ali splošnemu izobraževanju in da ostaja pri nas poklicno in strokovno izobraževanje še vedno nekako na robu civilnega interesa. V svetu se to že dolgo obrača v drugačno smer. Bolj ali manj je jasno, da je splošno izobraževanje razmeroma zadovoljivo strukturirano, čeprav je splošno priznano, da so konceptualne rešitve na ravni obveznega izobraževanja še dokaj nedorečene. Toda mogoče je opaziti stalno naraščanje zanimanja stroke in jaunosti za poklicno in strokouno izobraževanje. Vzroki za to so različni, osredotočajo pa se na tipično šolsko-politične zahteve po tem, da bi se poklicno in strokovno izobraževanje razvijala tako, da ne bi bila slepa ulica v izobraževalnem sistemu, ki posamezniku pri graditvi poklicne in delovne kariere zožuje in celo zapira pot ter mu zmanjšuje možnosti osebne rasti v življenju. Tako se tudi premislek o poklicnem izobraževanju skuša izmakniti tradicionalnim paradigmam, čes da je poklicno izobraževanje zgolj interes delodajalcev. Tudi glede vloge delodajalcev v poklicnem izobraževanju se odpirajo nove strateške usmeritve: 1. iščejo se nova partnerstva med izobraževalno in gospodarsko-poslovno sfero ter 2. poklicno/strokovno izobraževanje nista več razumljena le kot del sistema reprodukcije kadrouske sile, temveč tudi kot pogoj osebnega razvoja in socialne integracije posamezni$k a$. Obe navedeni strategiji sta za razvoj po-

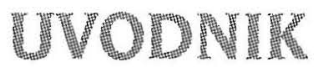

klicnega izobraževanja zelo ugodni, saj je njun skupni imenovalec, da se na poklicno izobraževanje ne gleda več z vidika ozkih pragmatičnih ciljev prilagajanja človeka delu, temveč z vidika globalnega razvoja tako imenovane kognitivne družbe.

$V$ prvem pomenu se pojem kognitivna družba uporablja kot sinonim za stalno učečo se družbo, za družbo, ki uveljavlja učenje in izobraževanje kot svoji temeljni razvojni značilnosti, kot ključna potenciala svojega razvoja. Najbrž se skuša usaj na šolsko-politični ravni tako povedati, da gre za več kot zgolj načelo permanentnosti izobraževanja. Gre za nekakšno univerzalno družbeno usmeritev, ki bi labko po-

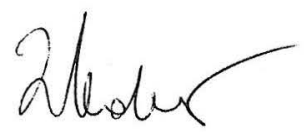
stala podlaga za to, da se vsako izobraževanje, zlasti pa poklicno in strokovno, oblikuje kot celovit sistem, ki povezuje temelino poklicno izobraževanje v mladosti ter stalno izobraževanje in učenje kot sredstvo osebnega razvoja posameznika, kot pot graditve njegove poklicne kariere, vir razvoja kadrouskib potencialov ter možnost spremljanja in ustvarjanja novega znanja. Brez takšne sistemske celote, ki vključuje izobraževanje za prvi poklic v mladosti, nadalinje izpopolnjevanje in usposabljanje ter tudi možnost priznavanja pridobljenega znanja z neformalnim izobraževanjem in lastnimi izkušnjami, ni več mogoče zgraditi učinkovitega poklicnegalstrokovnega izobraževanja. Načelo celovitosti sistema je tisti ključ, ki smiselno in logično utemeliuje možnost za preseganje poklicnega pragmatizma v izobraževanju za prvi poklic, saj je le na njegovi podlagi mogoče razviti široko profilirano temeljno poklicno izobraževanje v mladosti, kar je pogoj za veliko mobilnost $v$ zaposlovanju in delu ter tudi uspešno graditev poklicne kariere. Prav ta- 
ko je treba priznati, da dobiva danes $v$ poklicnem izobraževanju čedalje pomembnejše mesto tudi neformalno izobraževanje, ki bistveno dopolnjuje poti do poklicnega znanja in usposobljenosti.

Načelo celovitosti sistema poklicnega izobraževanja mora biti razvito tako, da omogoča uresničevanje dveh globalnih ciljev:

a) vzpon v poklicni hierarhiji, kar pomeni možnost za doseganje višjih izobrazbenih ravni, odpravljanje slepih ulic v izobraževalnem sistemu in odpiranje poklicnega izobraževanja navzgor do najvišjih stopenj izobraževanja, kjer $v$ načelu ne sme biti izključena tudi možnost dostopa do univerzitetnega študija, pri čemer naj bi se upoštevali zlasti strokovno znanje, vrhunska praktična poklicna usposobljenost in dosežki, ter

b) možnost sistematičnega obnavljanja znanja, spremlianja najnovejših dosežkov $v$ stro$k i$, doseganja specializiranega poklicnega znanja in spretnosti in navsezadnje tudi možnost sodelovanja pri nastajanju novega znanja.

$V$ drugem pomenu pa je pojem kognitivne družbe za poklicno izobraževanje še pomembnejši od opisanega. Gre namreč za kognitiuno prevrednotenje vloge, ciljev, pomena in končno tudi načina izvajanja poklicnega izobraževanja. Gre za to, da se poklicno/strokovno izobraževanje univerzalizirata. Univerzalizacija poklicnega izobraževanja pomeni zlasti zabtevo, da se v poklicnem izobraževanju zagotavlja razvoj vseh posameznikovih ključnih sposobnosti ali usposobljenosti (tudi ključnih kvalifikacij). Danes je že nesporno jasno, da mora vsako izobraževanje, torej poklicno in splošno, temeljiti na enakovrednosti treh ključnih področij razvoja sposobnosti oziroma usposobljenosti posameznika, to so: strokovnost, razvoj socialnih sposobnosti in doseganje osebne zrelosti (razvoj sposobnosti samostojnega zrelega odločanja).

Strokovnost se najpogosteje opredeliuje s tem, kakšno znanje (teoretično in praktično), spretnosti in navade mora zagotavljati izobraževanje. V poklicnem izobraževanju je to cilj, ki ga labko razčlenimo z znanimi pojmi, ki smo jib že navedli: mojstrstvo, strokovnost, delovna rutina in izurjenost. S tega vidika je mogoče trditi, da je poklicno izobraževanje $v$ svojih tradicionalnib oblikab usmerjeno zgolj $k$ doseganju »strokovnosti «, ki pa se je glede na rokodelsko tradicijo, pa tudi interese industrije, razumela na ravni množičnih poklicev, predvsem kot strokounost pri izvajanju delovnega procesa. Danes se v zvezi s strokovnostjo skilša doseči prevrednotenje z večjim poudarkom na razvojnem razumevanju poklicnega strokovnega znanja. Tako se zahtevajo večja teoretizacija poklicne izobrazbe in hkrati tesnejša povezava med teoretičnim in praktičnim znanjem; na drugi strani pa radikalnejši odmik od tradicije, po kateri je kvaliteta oziroma odličnost poklicnega znanja vezana na prenos praktične usposobljenosti iz generacije mojstrov na generacije dijakov in vajencev. Zahteva se več refleksije, kritičnosti, samostojnosti pri pridobivanju in iskanju znanja za reševanje praktičnih problemov s praktičnim delom.

$Z$ vidika socialne integriranosti naj bi poklicno izobraževanje razvijalo tiste posameznikove socialne sposobnosti, ki ga ne glede na raven poklicne izobrazbe usposabljajo za komunikacijo, sodelovanje, mu omogočajo pozitivno identifikacijo s poklicem, identifikacijo s poklicnim etičnim kodeksom ter identifikacijo s cilji sodobne proizvodnje, prevzemanje poklicne etike, ga motivirajo za inventivno delo, reševanje socialnih in organizacijskih problemov.

Z vidika osebnostne zrelosti pa bi moralo tudi poklicno izobraževanje na vseh stopnjah posamezniku omogočiti, da razvije sposobnosti, ki imajo predvsem metodičen pomen, na primer usposobljenost za samostojnost pri načrtovanju, sposobnost obuladovanja informacijskih virov ter uporabe novih informacij pri reševa- 
nju problemov, sposobnost sprejemanja odločitev, sposobnost kritične presoje odločitev in kritične ocene delovnih rezultatov, analize $k a-$ kovosti dela in motiviranost za stalno učenje.

Če strnemo tezo o enakourednem pomenu strokounosti, socialnosti in osebnostne zrelosti za poklicno izobraževanje, bi labko na kratko rekli, da mora sodobno poklicno izobraževanje posameznika pripraviti ne le na prenovljeno strokovno izvajanje dela, na kar je osredotočeno tradicionalno poklicno izobraževanje, temveč na obuladovanje vseh elementov delovnega procesa, torej načrtovanje, analizo problemov in zbiranje informacij za njihovo rešitev, samostojno odločanje o rešitvi, pripravo in izvedbo dela ter nadzor in evalvacijo.

$V$ zadnjih letih je $v$ svetu opravljenih vrsta raziskav o zastopanosti ključnih vrst znanja in sposobnosti v poklicnem izobraževanju. V raziskavah ugotavljajo, da je enostranost pri določanju ciljev izobraževanja poglavitna ovira za to, da absolventi poklicnega izobraževanja ne morejo izrabiti možnosti za nadaljevanje izobraževanja, ki jih sodobne družbe zagotavljajo zato, da bi odpravile slepe rokave in državljanom omogočile dostop do višjih ravni izobraževanja. Absolventi poklicnih in strokounih šol so $v$ deficitu pred absolventi splošnoizobraževalnih srednjih šol ob vpisu nadalinjega študija ali izpopolnjevanja na vseh bistvenih področjih. Nekaj prednosti zanje se kaže samo $v$ točki strokovnosti, toda najpomembnejše vrzeli absolventov poklicnih šol so $v$ osebnostni zrelosti. Raziskave hkrati kažejo, da so za uspešno nadaljevanje izobraževanja in študija najpomembnejše predvsem komponente osebnostne zrelosti, komponente strokounosti pa celo najmanj pomembne. Nadaljnje izobraževanje namreč od svojih kandidatov pričakuje več samostojnosti pri načrtovanju in organiziranju izobraževanja, bolišo usposobljenosti pri iskanju informacij in virov, pozitiuna stališča do izobraževanja, več moti- viranosti za samostojni študij. Ugotavlja se, da deficitarnost absolventov poklicnih šol ni nekaj naključnega, temveč je rezultat tradicionalne poklicne pedagogike. Poklicna pedagogika se je začela odzivati na izzive sodobnega izobraževalnega sistema šele $v$ zadnjih desetletjih. Zdaj je težišče njenih prizadevanj prav $v$ iskanju ključnih vrst znanja in sposobnostiv poklicnem izobraževanju. S tem se naj bi preseglo dosedanje zanemarjanje razvoja socialnih sposobnosti in osebnostnega razvoja dijakov, vajencev ali odraslih udeležencev.

V sodobnem razvoju si ni mogoče zamišljati kakovostnega poklicnega izobraževanja samo $v$ šolah, brez sodelovanja organizacij delodajalcev, brez njihovih tehnično-razvojnih potencialov, ki so pomembni za pridobivanje novega znanja. Zato je nesporno, da je treba iskati nove poti sodelovanja med izobraževalno in gospodarsko-poslovno sfero. Danes enostavno ni več mogoče zaupati spontani vzgojni ali izobraževalni funkciji dela. Delo ima vzgojno oziroma izobraževalno funkcijo le pod določenimi pogoji. V ZDA so dokazali, da se z izboljševanjem možnosti za izobraževanje na delovnem mestu povečuje tudi delovna produktivnost. Izboljševati možnosti pa je pomenilo predvsem organizirati delovno mesto tako, da postane delo kompleksnejše, manj rutinirano, usmerjeno $v$ reševanje problemo $v, z$ večjim poudarkom na timskem sodelovanju in večjo posameznikovo avtonomijo pri organizaciji in pripravi del ter tudi izbiri rešitev. Torej se spet vračamo $k$ enaki zgodbi, $k$ enakovrednosti strokovnosti, socialne usposobljenosti in osebnostne zrelosti. To naj velja za vsako izobraževanje tudi neformalno. Vsi trije cilii naj postanejo podlaga za določanje izobrazbenih standardov in standardov poklicne usposobljenosti. Le ob njihovi enakourednosti bo mogoče najti sistemske rešitve za priznavanje (ne)formalno pridobljenega poklicnega znanja in usposobljenosti, ki se obeta z uvajanjem tako imenovanega certifikatnega sistema. 